\title{
Managing information cycles for intra-organisational coordination of humanitarian logistics
}

\author{
E.A. van der Laan* \\ RSM Erasmus University, \\ P.O. Box 1738, 3000 DR Rotterdam, The Netherlands \\ Fax: +31(0)10-4089010 \\ E-mail: elaan@rsm.nl \\ *Corresponding author
}

\section{M.P. de Brito}

TBM-Delft University of Technology, P.O. Box 5015, 2600 GA Delft, The Netherlands

E-mail: m.p.debrito@tudelft.nl

\section{P.C. van Fenema}

Netherlands Defense Academy and Tilburg University, P.O. Box 90002, 4800 PA Breda, The Netherlands

Fax: +31(0)76-5274431

E-mail: pc.v.fenema@nlda.nl

\section{S.C. Vermaesen}

\author{
Alumna, RSM Erasmus University \\ E-mail: stefanie.vermaesen@accenture.com
}

\begin{abstract}
As the humanitarian aid sector is expanding, the need for enhancing coordination capabilities increases as well. This holds especially for the area of logistics, because humanitarian operations typically take place in unstable and risky environments, where infrastructure is poor, while staff turnover is high. The effectiveness of humanitarian logistics critically depends on the availability and quality of logistics support information, but data is often scarce and ICT support to remote areas is limited. The challenges caused by these constraints call for conceptual insight into the intra-organisational coordination process in humanitarian aid. In order to assess current practice of intra-organisational logistics information management for humanitarian aid, we combine humanitarian logistics and organisational literatures to develop a model that ties in information cycles with activity cycles that ultimately should lead to value creation. The model serves as a basis to analyse coordination practice at the Dutch filial of Médecins Sans Frontières (MSF-Holland) and develop implications for research and practice.
\end{abstract}

Keywords: intra-organisational coordination; humanitarian logistics; information management. 
Reference to this paper should be made as follows: van der Laan, E.A., de Brito, M.P., van Fenema, P.C. and Vermaesen, S.C. (2009) 'Managing information cycles for intra-organisational coordination of humanitarian logistics', Int. J. Services Technology and Management, Vol. 12, No. 4, pp.362-390.

Biographical notes: Erwin A. van der Laan (PhD, RSM Erasmus University) is an Associate Professor at RSM Erasmus University, where he teaches operations management and logistics. His research interests include knowledge transfer and performance management in humanitarian supply chains, reverse logistics and operations of sustainable supply chains. His work has been published in Management Science, Operations Research, European Journal of Operational Research and Production and Operations Management, among others. Another paper on the topic of humanitarian supply chains, co-authored with Marisa de Brito, is forthcoming in the International Journal of Risk Assessment and Management.

Marisa P. de Brito ( $\mathrm{PhD}$, Erasmus University Rotterdam) is a Lecturer at TBM - Delft University of Technology and a Research Associate at OTB's Institute of the same university. Her research interests include performance measurement and value creation in both humanitarian and sustainable supply chains. Her work has been published in the European Journal of Operations Research and the International Journal of Production Economics, among others. Another paper on the topic of humanitarian supply chains, co-authored with Erwin van der Laan, is forthcoming in the International Journal of Risk Assessment and Management.

Paul C. van Fenema ( $\mathrm{PhD}$, cum laude, RSM Erasmus University) is an Associate Professor at Netherlands Defense Academy and works part-time at Tilburg University. He held positions as an Assistant Professor at RSM Erasmus University, and as a Visiting Researcher at Florida International University. His research focuses on coordination of global projects and high reliability organisations. His work has been published or is forthcoming in, among others, MISQ Quarterly, Communications of the ACM, Information Systems Journal, European Journal of Information Systems, and Cognition Technology \& Work. He co-authored Knowledge Processes in Globally Distributed Contexts (Palgrave, 2008) with Kotlarsky and Oshri.

Stefanie C. Vermaesen (MSc) is a graduate from RSM Erasmus University. She wrote her Master's thesis on the topic of knowledge transfer within humanitarian organisations after an internship at Médecins Sans Frontières in Amsterdam. Much of this paper is based on her thesis research. Currently, Stefanie is working as a Management Consultant at Accenture. Her specialisations are supply chain management and sourcing and procurement. Her research interests include humanitarian supply chains.

\section{Introduction}

The importance of logistics in humanitarian aid was recently emphasised by disasters such as the Asian Tsunami in 2004 and hurricane Katrina in 2005. While humanitarian aid organisations are well-known for their short-term emergency relief, an important portion of their operations concerns long-term developmental projects as well (Minear et 
al., 1996). The sector of humanitarian organisations has expanded considerably, both in number of organisations as the amount of funds that are managed. These developments emphasise the need for enhanced coordination capabilities, both within and between humanitarian organisations.

One area that faces particular pressure to enhance its performance is humanitarian supply chain management. Although its activities are very similar to commercial supply chains (Beamon, 2004; van Wassenhove, 2006) they typically take place in socially complex and politically instable environments, where infrastructure is poor, custom clearance is troublesome and theft is a common risk. Also, the organisational context of humanitarian logistics is quite different (Powell, 2003), since humanitarian aid organisations are temporary organisations with high staff turnover, operating in geographically dispersed areas. These specific challenges - see also Kotlarsky (2005), Carmel and Tjia (2005) and Shapiro et al. (2005) - call for more conceptual insight into the intra-organisational coordination process in humanitarian aid.

In the past, humanitarian organisations have mainly focused on primary value adding processes such as medical services, but have given insufficient attention to their logistics capabilities. This has resulted in ad hoc operations oftentimes relying on only a few experienced logisticians (Thomas, 2005). The effectiveness of humanitarian aid also critically depends on logistics information and knowledge management (Zhang et al., 2002; Oloruntobar and Gray, 2006). Humanitarian organisations are currently much more aware of the fact that successful goods and fund raising does not suffice for effective humanitarian operations; goods have to be distributed timely and effectively to the ones in need and this implies a strong intra-organisational management of knowledge and information. The latter is extremely challenging as data is often scarce, unreliable and poorly supported through information and communication technology (ICT) (Rietjens et al., 2007; Stephenson Jr., 2004; Weiss and Collins, 2000).

Although inter-organisational coordination has received much attention (Kovács and Spens, 2007; van Wassenhove and Samii, 2003), few authors provide directions for improving intra-organisational coordination. In this paper, we assess current practice of intra-organisational logistics information and knowledge management in humanitarian aid organisations. The objective of our study is to provide more insight into the challenges and effective management of information and knowledge throughout project lifecycles in humanitarian aid organisations. We want to emphasise that compared to multinationals with decades or centuries of experience in global business, humanitarian aid organisations lack experience and access to resources (knowledge, advanced ICT and networks). Moreover, humanitarian aid commonly involves areas that are difficult to access and it concerns relief projects rather than long-term supply relationships. In order to understand the challenges emanating from these circumstances, we combine literature sources to first develop a model that ties in information cycles with the activity cycles that ultimately should lead to value creation in the humanitarian supply chain. The model subsequently serves as a basis to analyse information and knowledge management at the Dutch filial of Médecins Sans Frontières (MSF-Holland) through an extensive case study.

In spite of its known excellence in logistics (Paho/Who, 2001), MSF still faces logistic knowledge and information challenges. MSF-Holland is an important case, as it has recently initiated a trajectory of improvement with the aforementioned focus. First stage is problem identification, of which the research reported here is an important part. In this paper, we identify the major issues regarding MSF-Holland's intra-organisational coordination and provide directions for improvement. As MSF can be seen within best 
practices in the field, our results are likely to extend to other humanitarian organisations as well.

The remainder of this paper is organised as follows. Section 2 develops the model based on relevant theory, while Section 3 describes the research design. Section 4 provides a general description of the organisational structure of MSF and MSF-Holland in particular. The case of MSF-Holland is thoroughly analysed in Section 5 (local processes) and Section 6 (cross level processes). Finally, Section 7 discusses the main findings, their implications for theory and practice and some directions for further research.

\section{Conceptual background}

\subsection{Humanitarian aid organisations and logistics}

The sector of humanitarian aid organisations has expanded considerably. In the last decade alone, the number of international non-profit organisations (NGOs) has more than quadrupled from 6,000 to 26,000 (Medair, 2002). While humanitarian aid organisations have traditionally been small, operated by volunteers motivated by the 'philanthropic' character of the work, some have grown substantially, managing millions of euros in raised funds. These developments emphasise the need for enhancing coordination capabilities, in particular in the area of humanitarian logistics.

There is not yet a universally accepted definition of humanitarian logistics. In the 2004 humanitarian logistics conference in Geneva, humanitarians observed that complex discussions were sometimes impaired by the absence of a standard definition of logistics. The Fritz Institute initiated a working group to reach a 'common definition for logistics in the humanitarian world' (www.fritzinstitute.org/). Proposed definitions were based on the traditional definition of logistics ('the process of planning, implementing and controlling the efficient, cost-effective flow of and storage of goods and materials as well as related information, from point of origin to point of consumption', see e.g., www://cscmp.org/), followed by a humanitarian add-on, such as "for the purpose of alleviating the suffering of vulnerable people" (Thomas and Kopczak, 2005) or "for the purpose of meeting the end beneficiary's requirements" (Thomas and Mizushima, 2005). Humanitarian logistics comprises after all traditional logistics activities such as procurement, transportation, warehousing and distribution (Kovacs and Spens, 2007) to deliver goods to those in need. However, it seems inappropriate to use 'point of consumption' in the first part of the definition, since beneficiaries are not considered consumers in the sense that they engage in an actively sought for commercial transaction. As van Wassenhove (2006) puts it, humanitarian logistics is "the processes and systems involved in mobilising people, resources, skills and knowledge to help vulnerable people affected by disaster". We suggest therefore substituting 'point of consumption' by 'point of emergency' in the following adapted definition: "Humanitarian logistics is the process of planning, implementing and controlling the flow and storage of goods and materials as well as related information, from point of origin to point of emergency, for the purpose of meeting the end beneficiary's requirements".

Because 'efficiency' and 'cost effectiveness' are normative attributes (on what logistics should ideally be) rather than descriptive attributes and because of the fact that 
efficiency is usually not the primary goal of humanitarian logistics (which rather are preparedness and timeliness) we also dropped those in the above definition.

As said, most logistics functions that are performed by humanitarian aid organisations are similar to those of commercial logistics. However, special attention is needed regarding preparedness and constraints management (customs clearance and quality of local facilities). Specifically, humanitarian aid logistics face the following constraints (see also Powell, 2003).

1 Resource constraints. From a resources point of view (Mahoney and Pandian, 1992), humanitarian aid organisations, relying in particular on (medical) relief expertise, lack skilled logisticians. This represents a resource specialisation and quality issue. Moreover, they face resource discontinuity issues due to high staff turnover. Expatriate staffs are usually employed on short-term contracts, which lead to continuous reorganisations of teams within projects and knowledge leakage. Likewise, Thomas and Kopzack (2005) point at the lack of institutional learning. There is little opportunity to capture 'lessons learned' due to extremely high turnover of personnel and the lack of time taken to transfer knowledge after mission completion. Thus, specialisation and discontinuity of resources may jeopardise the quality and continuity of value creation.

2 Process constraints. Logistics flows, often crossing international borders and thousands of miles to connect sourcing areas to low-development areas, face multiple constraints such as transportation, clearance, and theft. Humanitarian aid organisations operate in diverse geographical areas depending on the occurrence of emergency or the overall weakness of a region's economic and medical infrastructure. This geographical dispersion translates into organisational distributedness: humanitarian aid organisations can be considered "decentralised systems, lacking an overseeing mind" (Tsoukas, 1996). Though modern communication technology is of valuable assistance, remote areas in which humanitarian aid organisations operate lack a reliable technological infrastructure. Furthermore, information technology, when present within organisations with heterogeneous cultures, remains challenging and calls for 'distributed organising' capabilities (Orlikowski, 2002).

Internal coordination in humanitarian organisations thus faces resource and process constraints, calling for conceptual insight into the coordination of those processes that ultimately should lead to value creation.

\subsection{Research model: coordination of activity and information cycles}

The value humanitarian aid organisations generate with their services highly depends on the coordination of their interdependent activities (Crowston, 1997). For instance, flying in time-sensitive and urgently needed medical supplies from Europe to projects in Ethiopia requires high quality coordination. This implies that hand offs and follow-up logistics are adjusted in terms of timing of flights, locations involved, temperatures on board transportation resources and quantities. Coordination of activities, often conceived of in terms of plan-do-check-act cycles (Tague, 2004) enhances their synergetic value (Galunic and Rodan, 1998). This value enhancement is achieved through the adjustment 
of activity properties which are represented in informational terms: when does the flight arrive, what quantities are needed, etc. (Galbraith, 1973).

Activity cycles both require and generate information (Stinchcombe, 1990; Galbraith, 1973). While coordination theory has studied the drivers of quantitative information processing needs, only recently it has started to explore in closer detail information cycles (Nevo and Wand, 2005; Oshri et al., 2008), and the relationship between information processing and activity cycles. Information cycles are often conceptualised in terms of encoding, storing and retrieving information (Wegner, 1987). More recently, Nonaka and Takeuchi (1995) emphasised that organisational knowledge conversion takes place through the 'conversion' processes between tacit and explicit knowledge. Conversion from tacit to explicit knowledge and vice versa occurs typically through team interaction, meetings, documentation, training, learning by doing, etc. (Nonaka, 1994). Hence, in this study, we emphasise the intertwined character of activity and information cycles for value creation (Figure 1).

Figure 1 Research model: coordination in humanitarian organisations

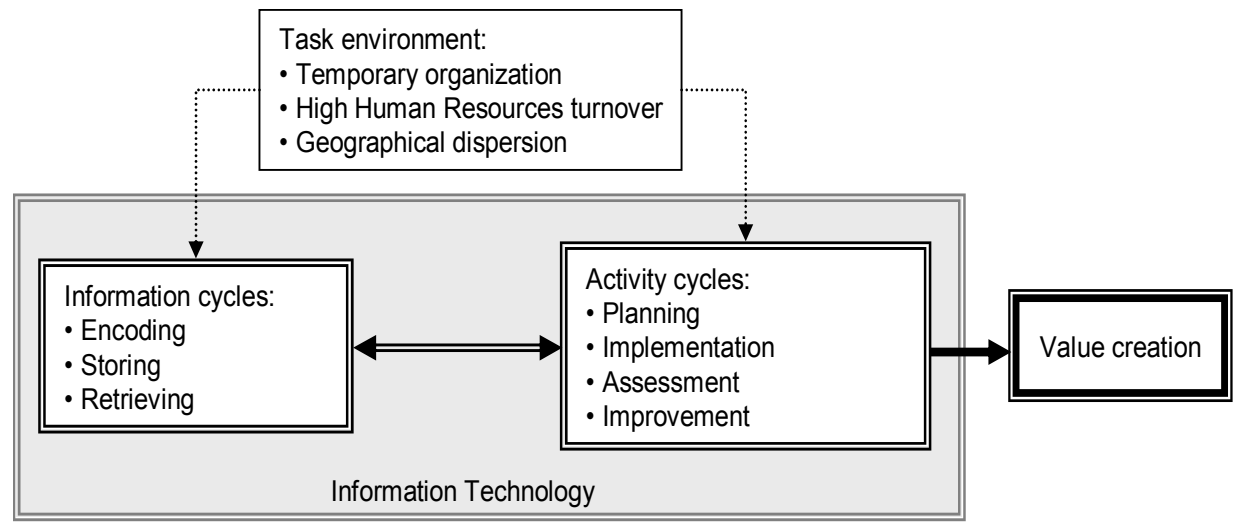

Source: Wegner (1987), Tague (2004) and Galbraith (1973).

Following theory, we assume that the characteristics of humanitarian aid organisations temporary organisation, high manpower turnover, geographical dispersion - affect activity and information cycles. That is, they are likely to impact the leveraging of project capabilities and value delivery (Owen et al., 2004).

\subsection{Intra-organisational coordination at humanitarian aid organisations}

Our emphasis on intra-organisational activity and information cycle coordination is motivated by the pivotal role of specific medical activities in humanitarian aid organisations and the ill-understood information processing challenges tied to these activities. Indeed, so far "there has been little emphasis on identifying what information is essential in relief, which stakeholders need it, how it should be used, or the way new technological tools can facilitate systematic data collection and communication" (IFRC, 1997) as cited in Zhang et al. (2002, p.374).

Adding to the complexity of coordinating activity and information, cycles is the distributed, multi-level nature of humanitarian aid organisations, also referred to as vertical differentiation (Rice and Shook, 1990). Functioning as a multi-level organisation 
(Bacharach et al., 1996; Van Fenema et al., 2007), their headquarters and mission coordination sites (commonly in capital cities of the countries in which they run projects) must coordinate their way of operating with the field. Activities in projects must be closely monitored to identify risks and resource needs. Headquarters and mission coordinators supply resources, guide activities, receive information on operations, and take decisions (Zhang et al., 2002). Studying the complexities and challenges associated with these interrelated processes across different levels of humanitarian aid organisations has received little attention thus far. Our study at MSF-Holland intends to contribute to this important challenge. Specifically, following our model as represented in Figure 1, we focus on interactions between activity and information cycles to identify instances of (lack of) coordination mechanisms and examine implications thereof for value creation. We presume in accordance with multi-level theorists that the characteristics of humanitarian aid organisations affect activity and information cycles at three levels of the organisation: headquarters, country's capital and field. After presenting our methods, we report our findings starting with an analysis of the local processes at each individual level, and then proceeding to the analysis of cross-level processes.

\section{Methods}

While studies on multi-level operations in organisations commonly assume collocation, current business and humanitarian aid organisations disperse activities tied to organisational levels across different sites. Our empirical study focuses on the Médecins Sans Frontières filial in The Netherlands (MSF-Holland), in particular the coordination challenges faced by staff at headquarters (HQ) in Amsterdam, logistics coordinators (LogCos) at the country's capital and logisticians (Logs) at the field level. We study these three levels and their interplay in terms of activity and information cycles.

\subsection{Case study design and data collection}

We employed the case study method through participant observation, which is an appropriate method to investigate 'complex phenomena' within the real-life context. This is especially relevant when this context is 'highly pertinent' to the phenomenon of study (Yin, 2003). For this research, the case study was conducted at MSF-Holland (MSF-H), a renowned organisation in the humanitarian sector and with more than 30 years of experience.

The case study was conducted during a period of about nine months. There were mainly three data collection methods (Ghauri and Grønhaug, 2005):

1 participant observation

2 interviews

3 questionnaires.

In order to ensure confidentiality, quotes will be coded throughout the paper (see Table 1). 
Table 1 Interviews and questionnaires at MSF-H

\begin{tabular}{|c|c|c|c|c|}
\hline Level & $\begin{array}{l}\text { Department/ } \\
\text { geographic } \\
\text { region }\end{array}$ & \multicolumn{2}{|c|}{ Position, number of interviews } & $\begin{array}{l}\text { Quotation code } \\
\text { (randomly) }\end{array}$ \\
\hline \multicolumn{5}{|c|}{ Interviews: July-September 2005} \\
\hline \multirow{8}{*}{$\begin{array}{l}\text { HQ } \\
\text { Amsterdam } \\
\text { Total: } 19\end{array}$} & FSU-Front office & $\begin{array}{l}\text { Department } \\
\text { Head (1) }\end{array}$ & Advisors (5) & FO1-7 \\
\hline & Total: (7 out of 7 ) & Team Leader (1) & & \\
\hline & FSU- Back office & $\begin{array}{c}\text { Team Leader (1) } \\
\text { ICT BO (2) }\end{array}$ & $\begin{array}{c}\text { Project } \\
\text { Coordinator (1) }\end{array}$ & BO1-7 \\
\hline & & & Field Support (1) & \\
\hline & Total: (7 out of 8$)$ & Supply chain (1) & & \\
\hline & & & $\begin{array}{c}\text { General Support } \\
\text { (1) }\end{array}$ & \\
\hline & Additional total: 5 & Procurement (1) & Specialist IDC (2) & ADD1-5 \\
\hline & & ICT general (1) & $\begin{array}{c}\text { Systems } \\
\text { Coordinator IDC } \\
(1)\end{array}$ & \\
\hline \multicolumn{5}{|c|}{ 2(a) Questionnaire (Q1): July-August 2005} \\
\hline $\begin{array}{l}\text { Country's } \\
\text { Capital } \\
\text { Total: } 18\end{array}$ & $\begin{array}{l}\text { Africa, Asia and } \\
\text { Eastern Europe } \\
(18 \text { out of } 30)\end{array}$ & \multicolumn{2}{|c|}{ Logistic Coordinators (LogCos) } & $\log \mathrm{CO} 1-18$ \\
\hline \multicolumn{5}{|c|}{ 2(b) Questionnaire (Q2=Q1+open questions): June-July 2005} \\
\hline $\begin{array}{l}\text { Field total: } \\
10\end{array}$ & $\begin{array}{l}\text { Africa, Asia and } \\
\text { Eastern Europe } \\
\text { (ten out of } 13 \text { in } \\
\text { training course) }\end{array}$ & \multicolumn{2}{|c|}{ Logisticians (Logs) } & LOG1-10 \\
\hline
\end{tabular}

Regarding the first collection method, one of the researchers spent several days a week at the Field Support Unit (FSU) of MSF-H headquarters in Amsterdam for a period of nine months, where explicit knowledge (e.g. formal reports) and tacit knowledge (informal talks with employees during coffee breaks) were used to get to know the organisation. Semi-structured interviews were carried out at MSF-H headquarters between July and September 2005. The questions were designed to gain a broad perspective of the coordination challenges MSF-H is dealing with in the area of logistics information and knowledge management. Interviews were carried out and recorded in person with 19 key stakeholders. 14 of the interviewees were from FSU, both front and back offices, including the department head, team leaders and advisors. The remainder interviewees belonged to the Information Documentary Centre (IDC) or to the Procurement or ICT department. The duration of each interview was approximately one hour.

In addition, two questionnaires were used: One questionnaire (Q1), with closed-questions, was sent to LogCos at the Capital level; the other questionnaire (Q2) was given to the participants attending an MSF-H Technical Logistics Course, containing both closed and additional open questions. The attendees of the course were Logs that had been on several missions in different countries. Both questionnaires ended with space for additional comments. Q1 was sent out in the summer of 2005 to the $30 \mathrm{LogCos}$ 
working for MSF-H. In total, 18 completed the questionnaire, corresponding to a response rate of $60 \%$. Q2 was handed out to 13 MSF-H Logs attending the two-week Technical Logistics Course of 2005 and ten completed the questionnaire.

Furthermore, preliminary findings were discussed directly with HQ and LogCos. For instance, a few months after the questionnaires and interviews were carried out, interim results were presented and discussed in small focus groups at the Annual LogCo Days (Malhotra and Birks, 2003). The participants made strengths/weaknesses analysis of the suggestions put forward. This was later used to consolidate the findings and to make a proposal on how to tackle problems concerning accessibility of information to the field. More details on how the questionnaires and interviews are linked to the research model can be found in Appendix 1.

\subsection{Data processing and analysis}

In order to achieve our research goals, we applied common methods of data processing and analysis (Corley and Gioia, 2004; Miles and Huberman, 1994; Lee, 1989; Edmondson et al., 2001). Miles and Huberman (1994) distinguish three steps in qualitative data analysis: data reduction, data display, and conclusion drawing with verification. Likewise, we analysed the data supporting the following objectives: to examine interactions between the activity and information cycles, to identify instances of (lack) of coordination mechanisms, and to extract the respective implications for value creation. Our initial theoretical perspective presumes that the characteristics of humanitarian aid organisations affect activity and information cycles at the three levels of the organisation: HQ, country's capital and field. We report our findings, starting with an analysis of the local processes at each individual level, and then going into the analysis of the cross-level processes.

Our analysis process followed common practice in qualitative research (Corley and Gioia, 2004; Miles and Huberman, 1994; Lee, 1989; Edmondson et al., 2001). As these studies show, qualitative analysis is a complex process that combines individual and collective work (e.g. coding and discussing results), interpretation and application (e.g. distilling themes and instrument-based coding). Likewise, our analysis proceeded through the following phases.

1 In the first phase, we organised the data files, shared these among the four authors and developed a descriptive story of the case. Key definitions and themes were elicited from the case and discussed.

2 Coding instrument. Next, in Microsoft Excel, we developed an instrument for coding data segments (sentences or short paragraphs) based on the research goals and model (see Figure 1) and our interpretation of the data at this stage. The following codes were used:

- value creation

- activity cycles (planning, implementing, assessing, improving)

- information cycles (encoding, storing, retrieving)

- linkages between activity and information cycles 
- task environment (task itself, resource availability, security, development of the organisation, broader task context)

- $\quad$ ICT/IS (types of IS, ICT infrastructure, strategies for using IS).

3 Independent coding. Each author independently coded data segments using this instrument.

4 Discussing coded files. The files containing coded data were shared and discussed. We then identified and refined recurrent themes, and developed the structure of the findings section.

5 Structuring the findings. We structured our findings section according to two dimensions; first, local and cross-level processes, and second, activity and information cycles. We used the first dimension for clarity of presentation of our findings. The second dimension captures the key concepts from our research objective.

Above phases were pursued in an iterative fashion until consensus was reached, furthering our understanding of challenges faced by MSF-H.

\section{MSF-Holland}

\subsection{MSF organisation}

Médecins Sans Frontières (MSF) was first established in 1971 in France. It has grown considerably since then, including nineteen filial sections around the world, such as Canada, USA, Japan, Hong-Kong, Australia and various European countries. Five of these sections (MSF-Holland, Belgium, France, Spain and Switzerland) are operationally active in missions worldwide with a mission expenditure of about $€ 457$ million and 27,000 staff in 2006 (MSF, 2005). The other sections are mainly active in raising funds and selecting human resources for the operational sections. According to MSF (http://www.msf.org) its primary objectives are "providing medical aid wherever needed, regardless of race, religion, politics or sex and raising awareness of the plight of the people we help". The majority of projects at the time of research in 2005 were carried out in Africa (69\%) and Asia (23\%). Many of them (47\%) were located in unstable settings. The funding for the projects comes mainly $(86 \%)$ from private sources comprising 3.4 million donors.

MSF assists populations with medical care in countries were either there is a sudden emergency, or where the health structure is rather poor. The latter comprises a large portion of MSF's aid efforts. As these projects are often for the longer term and can often be duplicated in other countries, they especially offer opportunities for institutional learning and organisational improvement. Though MSF considers it rather important to operate independently, MSF often cooperates with local organisations and governments to put in place health programs, for instance the national Ministry of Health. MSF also trains local workers and strives to create awareness for areas in crisis.

MSF-H is one of the filial organisations that are active in missions. Until October 2006, MSF-H operated in a partnership with MSF-Germany, Canada and UK. Missions were carried out together with MSF-Germany, whereas MSF-Canada and UK raised 
funds and selected human resources for these operational sections. As of October 2006, MSF-H has reinforced that strategic partnership and is now dubbed the Operational Centre Amsterdam (OCA). OCA currently operates in about 30 countries across four continents (see www.artszondergrenzen.nl). MSF-H headquarters in Amsterdam coordinates all projects and provides support to the mission staff, which includes medical, logistics, and financial staff plus other specialists. Mission staff can be either international staff that is allocated to the crisis area, or staff sourced from the crisis area itself. Annually, MSF-H sends out about 1000 international staff members to the field, while local staff is about 6000 . The people working at the field level provide the actual aid and they are coordinated by staff at the capital level.

\subsection{Management of logistics support information}

The HQ of MSF-H has a functional division into five main operational departments supporting the field: the public health department (medical and water and sanitation), the logistics department, the financial department, the HR department and the humanitarian affairs department. The logistics department consists of a procurement unit, which is responsible for processing all international orders from the field, and an FSU, which deals with all logistics (information) requests from the capital level. The FSU itself is divided into a front office and a back office. The front office is a collection of sections, each operated by one person that is responsible for a certain geographical area (portfolio). In the back office, support is available on a particular topic, e.g. ICT, supply, cold chain, energy, transport, etc. The back office exchanges information with the front office, if relevant to the field. Figure 2 gives a schematic representation of the organisational units and information flows within MSF's global logistics organisation.

Figure 2 Organisational units and information flows within MSF-H (see online version for colours)

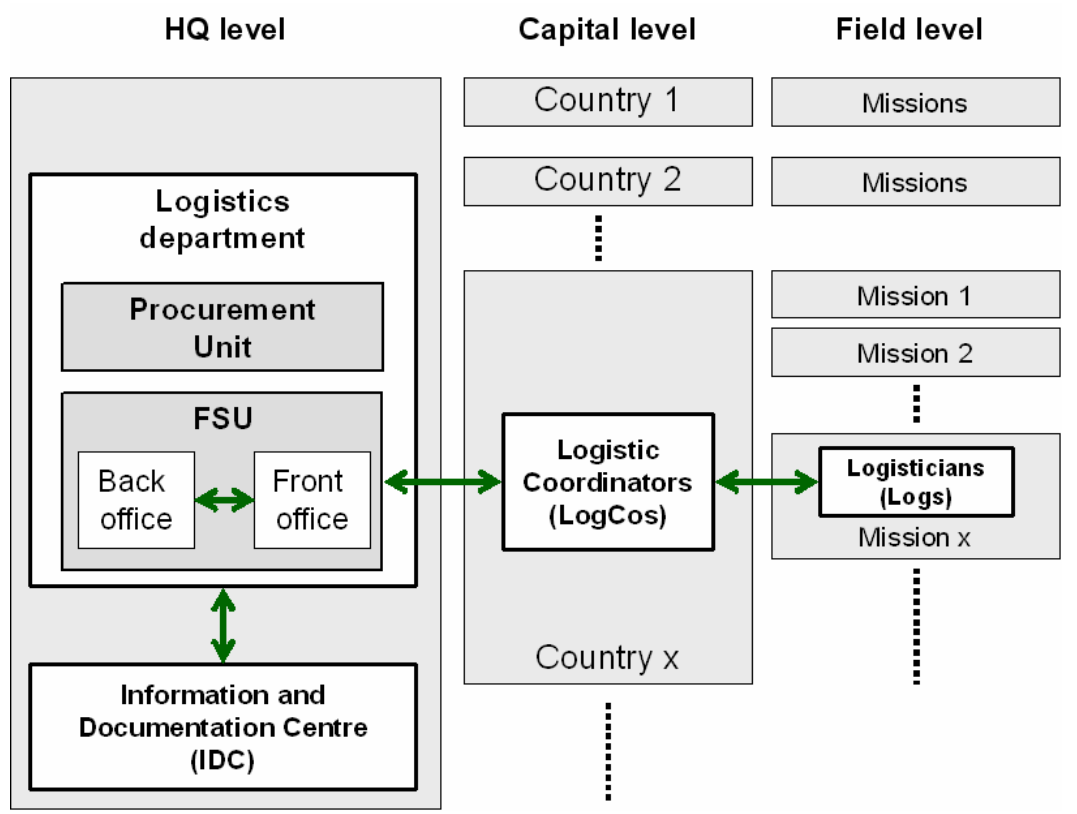


Currently, logistics information within MSF-H can be transferred, stored and accessed at three levels: HQ, capital and field level.

- At the field level, a logistic administrator (Log) is responsible for logistics activities in that particular project. Activities range from handling orders, supply, purchasing, stock, freight and administrative management. A Log reports to the project coordinator of a certain field mission concerning project related matters and to the logistics coordinator at capital level concerning any logistical matters.

- At the capital level, a logistics coordinator ( $\log C o)$ reports to the head of mission of a certain country concerning project related matters and to a front officer at HQ level concerning any logistics matters. The LogCo is responsible for the logistical support given to MSF's projects in a country (field level). Duties include managing supplies, local and international orders, security-related tasks, transports and communication resources.

- At HQ, the FSU has to its disposal a wide array of information platforms for information storage and downstream distribution. These include a logistics website, an FTP server to distribute large files, CD-ROMS and logistics reference material. Additionally, FSU may access a separate unit, the IDC operated at HQ, for any stored information regarding MSF-H projects and general information sources on humanitarian aid in general. For a detailed overview of all information platforms in use, we refer to the Appendix 2.

The logistics information that MSF-H distributes to the field is categorised according to the following topics: supply chain management, cold chain, energy and electricity, communications technology, transport management and mechanics, building and shelter, and water, hygiene and sanitation. All of the logistics information comes under the responsibility of the logistics department, except for the latter, which is a responsibility of MSF-H's department of public health.

\section{Findings: local processes at MSF-H}

MSF-H as a humanitarian organisation with global operations has to carry out work in a distributed manner. Attached to the same mission there are geographically dispersed responsibilities. Missions will have a front office advisor at HQ who can be responsible for four or five projects in different countries, or even in different continents. In addition, staffs often accumulate multiple tasks: e.g. consulting and supporting roles (making regular visits to the field), training, back office tasks and front office country leadership.

MSF-H started as a relatively small organisation. Activities were carried out on a basis of trust and good communication contributed as one of the key factors for success, where short spans of control were in place. Past 'career' development has been roughly based on the following rationale: one time successful in the field, a person's responsibility 'doubled' during the next mission. The organisation has grown, not only in terms of projects and people, but also with respect to content, accumulating knowledge throughout the years. The organisation is seen to be in transition from the old model (small organisation with hard-working people) towards a new status (larger organisation 
needing more formal control mechanisms). Next, we present our findings on the activity and information cycles.

\subsection{Responsibilities and activity cycles}

According to the Project Management Institute (PMI Standards Committee, 2000) a project has four phases: initiation, planning, execution and closing. We focus on the operational phases of ongoing projects and therefore do not explicitly include initiation, or closing as a separate category. Initiation, in the case of MSF-H, is triggered by relief emergencies, rather external to MSF-H itself and of a more tactic/strategic character (which emergencies to attend to). Closing a mission in its turn would mean the end of operations and it is likewise of tactical/strategic character. In ongoing projects, the learning component is however very important. As put by Cooper et al. (2002), in project management 'we must learn how to learn' and 'how to extract and disseminate management lessons'. Given our focus on the operational phases of ongoing projects and the relevance of learning in project management, we find it appropriate to adopt Tague's (2004) project management cycle model (planning, implementation, assessment and improvement) in our analysis.

\subsubsection{Planning}

At HQ, some procedures are in the design phase. There are also suggestions about taking the new procedures or any future work standards a step further, like integrating them in training programs. Such integration is currently not yet in place. Regarding the division of responsibilities for information management, clarity of responsibilities is lacking. This appears to vary with departments: an interviewee stated that at the front office responsibilities concerning documentation were rather clear. Back officers are mainly responsible for updating guidelines but front officers may also share the responsibility. In principle, the updating process is coordinated as follows: the back office leads, and the front office follows, but it is not always evident what exactly this means in practice. At the field level, there is not so much time for planning, as Logs are kept busy doing their activities. The high turnover also causes plans not to stick for too long.

\subsubsection{Implementation}

Handovers at the field level, both in person and in writing, are rare. This tends to have negative repercussions on information management, performance and innovation (procedures have a short life, i.e. they are replaced by others as soon as a new LogCo is in place). Due to the short time span available, tacit knowledge is hardly transferred. At the field level, the daily work is characterised by a changing environment, where information is quickly outdated. Missioners, working long and intense hours both physically and emotionally, are action-oriented with little time for planning or reflection. They are focused on resolving daily needs at the expense of guidelines if necessary. Field workers usually function in isolation in remote areas, with limited external contact, even counting with co-workers from other missions in the same country or with the LogCo visits. In addition, workers are always 'at the scene', which leaves them with very little private space and time. 


\subsubsection{Assessment}

Reporting is a key instrument to monitor the status of activities. MSF-H has some 'rules' with respect to the reports that have to be written on. Reports are sent to HQ via the LogCo, who can decide to integrate reports from the logs in his/her own reports to make it a comprehensive document. Reports are not always sent (see also section on cross-level analysis). Also, it appears that more information on logistics should be included in the reports, so problems can be detected and anticipated as soon as they arise. A particular bottleneck with reporting is the understanding on the required level of detail. There are guidelines for reporting, but apparently, these do not specify up to what extent topics have to be reported. Therefore, not all LogCos know the expected length, or what exactly is expected to be elaborated in the reports.

In the absence of proper guidelines, LogCos have to use their own assessment of what is interesting to report and what is not. In addition, there are no enforcement mechanisms from MSF-H on this; neither any formal follow-up if someone does not carry out her 'reporting' job as supposed to. Currently, there is also a lack of performance indicators, but the organisation is taking steps in this area.

\subsubsection{Improvement}

Proper reporting is necessary to audit the status of the project and to give recommendations for improvements if necessary. While there has been internal research on the need for assessment and improvement (Keizer, 2003), MSF-H has not yet entirely implemented these ideas. Potential improvements with respect to performance call for: assigning clear responsibilities on who is accountable to monitor whose work (e.g. on reporting), timely information, and aligning work procedures with the new information systems and ICT. With respect to information, as an outcome of this research, a new protocol for information storing associated with a centralised website has been developed. This suggests that the organisation has the capability for leveraging from the point of assessing a problem to the point of improving. Yet, to fully exploit improving capabilities, the previous steps of the activity cycle need to be strengthened.

\subsection{Information cycles}

\subsubsection{Encoding}

At the HQ, encoding and information updating is a major issue, as the following quotes show: "There is also a lot of information that should be linked, but at the moment it is not clear which information belongs to which heading" (BO3). "At this moment they are just filing documents under names which might not even be understandable for the persons looking for it. And they are not saved within a certain index" (BO3).

The above stresses the absence of standard indexing and its negative consequences. In addition, the interviewees point at the lack of version control and ambiguity on who can insert what information.

\subsubsection{Storing}

Storing can be problematic because there are too many platforms where to store information (different servers, website, CD-ROMs, etc, see Appendix 2). It is not 
straightforward which platform to use for what type of information. This is challenging because not everywhere the ICT infrastructure is the same. For example, the CD-ROM remains necessary, as there will still be locations in the field not having internet access. Thus some information is stored in multiple platforms and 'the ownership' of information is fragmented across some departments. Thus, "The same information already has to be updated in three systems" (ADD3). "Information is kept in many sources" (ADD4).

The consequence of poor storage is loss of information, and limited extension of the organisation's memory. There were examples of projects running for two years without proper storage of information. Consequently, two years of institutional memory was lost, which negatively impacts future value creation.

\subsubsection{Retrieving}

MSF-H has to deal with technical limitations, especially at the field level. Not all information systems can be used at all levels, as the speed of communication gets very slow. The criticality occurs mainly at field level, where usually the ICT infrastructure is sparse: "Concerning the website ... there is a problem with connectivity here, since the field cannot access this website" (ADD1). "In the field, internet connection is too slow" (ADD3). "Habari is currently not an appropriate platform for the field, neither is Tukul. The last mentioned platform is technically not good enough. It is too slow, even in the office" (ADD1).

Immediate access to information such as end of mission files and registrations from the previous project in the region would have contributed to the adequacy of care provisioning. While there is information sharing between projects (especially in the same country), inter-country project learning appears more challenging: "Information sharing between projects is pretty much non-existing. Unless it is from the same mission (country), but then it is coordinated through the LogCo" (BO1). Information retrieval is further complicated through the diverse international background of MSF workers. People describe the same subject in different ways: "A big problem is the way different people describe the same subject in totally different ways (...) everyone looks under different keywords" (FO2).

We would like to stress, that every phase subsequently influences the next: e.g., poor encoding would lead to poor storing, and subsequently to difficulties in retrieving. In addition, the cycles themselves are interlinked: for instance, retrieved information is employed in the implementation of activities. Next section goes into more detail on the information and activity cycles across levels.

\section{Findings: cross-level activity and information cycles at MSF-H}

As a synopsis, MSF-H, like many other humanitarian organisations, has been facing two key challenges: the quality of information, and the division of responsibilities for information processing. These challenges - illustrated in the following quotes - constrain the quality of information cycles and thereby the value of information for effectively coordinating logistics activities. ".. there is clearly a demand for information, the question is: are we providing that in the most accessible way, high quality?" (BO-1).

"The LogCo in capital usually has good access to the internet, but he/she should then be responsible to distribute relevant information to the logs in the 


\begin{abstract}
projects. It is proven in the past that this does not work. Therefore, the FSU has decided to provide the FSU CD-ROMs to every project, to every log, distributed via the $\log C o$. The $\log C o$ should have responsibility for the logs working in his/her country concerning information distribution and access. Currently, this responsibility lies too much with the FSU ... responsibilities are not clear concerning procedures for documenting or retrieving information, not at HQ and neither in the field" (BO2).
\end{abstract}

Information cycles are directly or indirectly tied to activity cycles. For instance, when operational resources are sent to the field, they are accompanied by manuals and guidelines; resources returned to the LogCo or HQ come with reports and requests. To give another example, MSF field logs, contributing with logistical support to the multidisciplinary care teams in the field, are embedded in activity cycles that involve LogCos at the local capital and the MSF HQ in Amsterdam. HQ and LogCos ascertain the availability of medically specialised human resources in the field, and they provide or facilitate provision of operational resources, e.g. ICT, field operations resources, and medical technologies. Conversely, field logs may return operational resources for maintenance or repairs. These two examples of information cycles show their relevance for supporting coordination of organisational activities (Stinchcombe, 1990). We found several information cycles that are directly or indirectly linked to activity cycles. As will be elaborated below, these include downstream and upstream oriented cycles.

\title{
6.1 Downstream-oriented information cycles
}

\subsubsection{Guidelines}

Documents with guidelines and procedures on how to carry out the job represent an important linkage between activity and information cycles. Currently, MSF-H has two types of managerial documents containing procedures on how to carry out some parts of the job: recommended guidelines (so-called yellow cover documents), which have no obligatory character, and policies (red cover documents), which are mandatory. The organisation is developing procedures setting the core of the tasks, and at the field level volunteers can decide on how to schedule the rest of the activities. Developed by HQ and intended for standardising LogCo and field activities, guidelines appear inconsistent, outdated, at times inappropriate for particular field situations, and with different versions stored at different technological platforms (CD-ROM, internet, intranet, etc). Guidelines sometimes do not find their way from HQ to LogCo to the field since they are not provided directly to the first missioners. This represents an information distribution problem. Moreover, guidelines that were once distributed to the field sometimes disappear due to high turnover of staff. HQ does not enforce use of and compliance with these standards. At the LogCo and field level, guidelines are sometimes rejected; groups develop their own guidelines, partly unknown to HQ and without HQ using these. Some field workers feel that making oneself familiar with guidelines is not among their set of high priorities. Yet interviewees mentioned examples on how MSF-H learned the importance of having clear guidelines the hard way. The absence of these has led to supply problems in one large project in Africa. Particularly, insufficient information was available and responsibilities were unclear. Across a wide range of tasks, the field is still in need of guidelines from HQ. In addition, there is the need to revise some of the documents containing guidelines or policies, as some of them are outdated. 


\subsubsection{Advice}

When the field needs advice, they may contact LogCos or the HQ front office. "The LogCo is the person who knows which structure is chosen in that specific country, which tools are indeed used and which ones are not. And if they do not know, the front officers at HQ can advice them in these matters" (BO1).

Sometimes they contact the HQ's back office because the front office functions too slowly, causing sometimes confusion. Adding to this experience is MSFs switching between push and pull strategies for advising services. Their current pull strategy may not suffice for certain areas, and local staff may not be aware of this type of strategy.

\subsubsection{News provisioning}

In a global organisation, news on dispersed operations is important to sustain organisational consistency (Bacharach et al., 1996). Especially with emergency relief concerning multiple areas, information is time-sensitive and affects the quality of care. MSF-H successfully utilises message-posting functionality on their intranet platform to quickly inform their facilities. At the same time, some concerns surfaced. Firstly, if this mode of informing is successful, there is a risk of overload, i.e., communicating information through this channel that does not really constitute news but for instance a guideline. Secondly, information appeared difficult to access. Field workers become confused where to go to get what information. This seems a consequence of procedures for documenting information that lack clarity. And third, upon retrieving information, interviewees questioned its value: "You have to question yourself seriously what the value of that information is, concerning reliability" (ADD1).

\subsubsection{Training on information organisation and ICT}

MSF-H is investing in ICT expertise at the LogCos, pushing expertise downstream. This specialised expertise was lacking, resulting in HQ being overloaded with technical questions. In addition, MSF-H is inserting expertise on information organisation in standard training programs in order to prepare international field workers for their responsibilities in this area. "Supply standards which are currently being further developed should be integrated into training programs" (FO-1).

\subsection{Upstream-oriented information cycles}

\subsubsection{Reports from the field}

Field workers are expected to file reports on their activities, in addition to their usually intense operational care activities. The formatting and frequency of these reports lack standardisation, they depend on the individuals involved. The same applies to field reports made by visiting HQ staff. Reports that make it to the HQ are not read sufficiently or kept in a central place for reference. HQ is not unaware of this, as a template for filing reports has been proposed, passed on to the management team, and is waiting for approval. Until this happens, a huge amount of information, such as registrations within countries for projects, memorandums of understanding (MOUs), end of mission files, and information of contacts with other NGOs will be waiting in boxes to be physically stored and to be available as a source of reference. Naturally, the absence of such a template (to 
encode and store reports) is adversely affecting future activities (which cannot make use of the existing information). For instance, after the tsunami MSF-H urgently needed to gather information on a project in the region, which had, been closed for some years. It took almost a day to retrieve this information, so it could be fed into the emergency plan.

\subsubsection{Reverse logistics information}

Information on broken equipment in the field is inconsistently reported to the HQ or not reported at all. This limits HQ's insight into the value and constraints of operational resources and the need for taking actions, for instance vis-à-vis suppliers of equipment.

\subsubsection{Procurement}

Humanitarian missions require a variety of products, including medical, electronics, and regular supplies. In order to source these products from various suppliers, MSF-H processes a considerable volume of orders. HQ receives reports on these processes on a regular basis. "A more comprehensive report with annexes and updates on inventories, stocks has to be written every six months. Thus at the end of term, (the report) only has to be updated, if used adequately, as not all information changes every six months" (FO-2).

At times, it appears challenging to handle procurement as the following quote illustrates: "In some projects things go dramatically wrong, for example concerning stock outs" (ADD-5).

\section{Discussions}

In this paper, we set out to identify the major issues regarding intra-organisational coordination of logistics activities in the humanitarian context, focusing on information and knowledge management aspects. To this end, we combined humanitarian logistics and organisational literatures to develop a model that ties in information cycles with activity cycles that ultimately should lead to value creation. The model served as a basis to analyse coordination practice at the Médecins Sans Frontières organisation operating from The Netherlands (MSF-H). Below, we discuss the study's implications for MSF-H, and humanitarian logistics practice and research.

\subsection{Implications for MSF-H}

We have seen that the organisation in principle has the capability for leveraging from the point of assessing a problem to the point of improving. Yet, to fully exploit these capabilities, a number of issues need to be resolved.

\section{Guidelines}

Guidelines developed by HQ appear inconsistent, outdated and at times inappropriate for particular field situations. Moreover, different versions are stored at different information platforms. Although against HQ procedure, LogCos and Logs develop their own guidelines. Standardisation of logistics activities and procedures is crucial in an emergency environment where field workers often lack logistics skills and time is lacking 
to learn best practices on site. Unavailability of up-to-date, consistent guidelines or lack of discipline in following the prescribed guidelines negatively affect logistics value creation as several examples from MSF-H practice have shown. MSF-H needs to review its guidelines and enforce good discipline to follow those for instance through training.

In particular, guidelines for reporting lack standardisation in terms of content and level of detail. There are no repercussions if reporting is not done in a timely fashion. Proper handovers at the field level are rare. Practice shows that this negatively affects value creation as there is no knowledge transfer and mistakes repeatedly occur. The lack of specific logistics performance indicators prohibits improvement of logistics activities. Also here, MSF needs to review reporting guidelines and enforce reporting discipline.

\section{Information management}

Information management faces several issues. Despite abundant availability of information on several platforms, it is often unclear what information is available where. Version management is lacking, so information that is updated on one platform may not be available on another one, and there is no way of telling which version is the best. This is due to the fact that the ownership of information often is unclear and sometimes fragmented over multiple departments. Logisticians in the field rely on fast and reliable information to provide their services timely. If information cannot be found or cannot be trusted this will surely affect value creation in a negative way. It seems therefore essential for MSF-H to combine a sufficient level of information redundancy on the one hand with professional version management control on the other. For this, ambiguities with regard to responsibilities need to be resolved.

Switching between push and pull strategies for information provision has proved to be confusing. In the late 1990s, MSF-H transitioned from a push towards a pull organisation. At present, however, MSF-H applies a push strategy for MSF-H catalogues promoting standardisation. We recommend that demand from the field should drive information in order to avoid information overload. A related dilemma concerns the extent to which information requests follow official organisational patterns (often with multiple, chained links), or more direct and interpersonal paths across the levels. Sometimes the HQ front office responds too slowly, inducing field or LogCo workers to contact the back office. Also, the field may pull information directly from the website rather than contacting its $\log C o$. The $\log C o$, on the other hand, thereby would lose sight of issues at the field level through lack of personal contact with field workers. MSF-H should develop a more sophisticated, customised information strategy that consists of mixture of indirect and direct contact depending on the type of information, the audience, and local conditions in the field.

Partially based on our findings, MSF-H has initiated improvement programs in congruence with our implications sections. Only some time after implementation, we will be able to fully assess possible positive effects on value creation.

\subsection{Implications for humanitarian aid organisations: research and practice}

Humanitarian aid organisations are professionalising their service provisioning processes, in particular in the area of logistics (Kovács and Spens, 2007; van Wassenhove, 2006). Focusing on their value creation process, they operate across the globe, enacting short and long-term relief services in a heterogeneous network of local and international 
organisations. Our study provides insight into the process of value creation in humanitarian aid organisations and the associated challenges. Value depends on availability of skilled professionals and adequate resources. These deliver value through rapid deployment, fine-tuning of local activities, and coordination between local, regional and central levels of the organisation.

Humanitarian aid organisations are developing from adhocracies (Mintzberg, 1995) into professional bureaucracies. They become more predictable, in the sense of being capable of repeatedly organising ad hoc relief efforts in an efficient and effective manner. This requires strong capabilities for coordinating expertise management and logistics flows. Professionals responsible for this transition process face various constraints and challenges, such as standardising without losing flexibility, and investing without abundance of resources. While current research points at operational concerns and opportunities for improvement (e.g., Kaatrud et al., 2003; Transnational_Institute, 2001; Beauregard, 1998), few studies develop theories for framing the coordination challenges humanitarian aid organisations face. Our study encourages researchers in this field to think in terms of value creation processes driven by primary and secondary processes (Bollen and Beeres, 2008; Porter, 1998). The primary process - the care provided in problematic areas that are often difficult to reach - requires local and global support networks. Focusing initially on intraorganisational coordination at MSF-H across three levels, our study develops and refines a model that links information and action cycles with value creation and ICT. From this study, we derive a number of pointers for humanitarian aid organisations that apply to intra- and inter-organisational operations.

\section{Structures without comprehensive bureaucratisation}

Organisational structure promotes knowledge deployment and efficiency of communications (Adler and Borys, 1996; Hinds and McGrath, 2006), and its role in global organisations such as offshore software development or humanitarian aid organisations has been stressed (Paasivaara and Lassenius, 2003; Rietjens et al., 2007). At the same time, the pressure on local field workers and resource constraints in remote areas limit the usefulness of elaborate role descriptions, reporting procedures and so forth. Hence, humanitarian aid organisations would benefit from minimal structures (Kamoche, 2001) that set the boundaries for professional workers, customised to their role and situation in order to reduce their burdening impact. Standardisation of such minimal rules (so-called harmonisation) promotes inter-organisational coordination and exchange.

\section{ICT infrastructure}

Information and communication infrastructures need to transition into global networks, consisting of a variety of high and low tech infrastructures. Minimal and open standards will allow for interoperability across the levels of humanitarian aid organisations and between these and other types of organisations (Fewell and Clark, 2003). Technology platforms will continue to differ per region (e.g., low capacity radio networks in Africa) and this heterogeneity must be taken into account. 


\section{Information and knowledge flows at the local level}

Considering local hand offs from a knowledge management point of view implies that these influence the quality of local value creation. Humanitarian aid organisations deploy professionals for limited periods of time, hence the need for managing hand offs carefully (Kumar et al., 2005).

\section{Information and knowledge flows across levels}

Apart from local hand offs, knowledge acquired during projects in the field must be reported to regional centres and headquarters without burdening professionals checking out from local assignments. This dilemma can be solved by developing standardised, accessible forms accompanied by clear instructions. Downstream and upstream information flows must be reconsidered on the basis of key principles such as affordability, need-to-know, ease of use and optimisation of value/effort ratios. Due to the nature of humanitarian aid organisations, with limited resources and time available, professionals must carefully handle information processing and infrastructure dilemmas based on these principles. Kotlarsky (2005) argues that effective knowledge sharing in project teams facing cultural, geographic and time zone differences is challenging. Applied to humanitarian organisations, staff should be encouraged to adapt their behaviour in order to ensure consistency across all levels and to ascertain value creation in short and long term missions.

\section{Knowledge on the long term: collective memory}

Beyond the day-to-day flows of knowledge, our study shows that local expertise must be transferred and stored globally. This problem of unstickying and transferring information (von Hippel, 1994) calls for organisational mechanisms for absorbing, transferring and delivering information. If knowledge is not held in the organisation's memory, lessons cannot be drawn from the past (Oshri et al., 2008; Huber, 1991; Kaghan and Lounsbury, 2006). Humanitarian aid organisations need to develop capabilities to transfer and incorporate knowledge on a global scale, taking into account the partly idiosyncratic nature of their projects and the sites they operate in Orlikowski (2002).

\section{Intra-inter organisational coordination}

Finally, while our study contributes to literature on intra-organisational coordination, it has implications for inter-organisational coordination (Smith et al., 1995; Bollen and Rietjens, 2008). Between organisations, information processing and communication processes are required for achieving economies of scale, synergy, resilience and learning (Powell et al., 1996; Stephenson Jr., 2004). Specifically, inter-organisational coordination capabilities depend on interconnected infrastructures, sharing logistics and ICT expertise across organisations, and definition of responsibilities across organisations. These mechanisms for ensuring the quality of inter-organisational value creation closely relate with increasing intra-organisational capabilities. For instance, clarity if internal division of responsibilities facilitates interaction with other organisations on work breakdown structures. 


\subsection{Limitations and future research}

Like any study, our study faces limitations. Our data collection covered mostly HQ staff and LogCos. Given the constrained accessibility to Logs, they were less represented. Facing the need to develop capabilities for global logistics coordination, we focused on intra-organisational coordination. Future research may examine how humanitarian networks coordinate across organisational levels and sites. This would provide rich and useful insights into the drivers of global logistics coordination and humanitarian aid services, and answer the recurrent calls for multilevel studies on intra- and inter-organisational coordination (Smith et al., 1995; Gittell and Weiss, 2004).

Another issue of paramount importance for value creation is collaboration, i.e., working with complementary entities (departments, organisations, supply chains, etc.) in order to achieve innovative approaches for facing new challenges (Denise, 1999). Though there is some recent literature addressing this at the partnership level (Tomasini and van Wassenhove, 2004; O'Sullivan and Wild, 2007), collaboration has not yet been thoroughly investigated in the humanitarian logistics context. There may be some lessons from commercial supply chains, in particular on efficient consumer response (ECR) and collaborative planning forecasting and replenishment (CPFR) in the grocery sector (see Kurt Salmon Associates, 1993; Fernie and Staines, 2001; Holmstöm et al., 2002). This should be formally investigated.

We build our conceptual model based on literature primarily for structuring the analysis; our goal was not to validate it. As the model generated useful results, we have some confidence that the model is valid. This, however, should be formally tested.

Only some time after implementation of MSF-H's plans for improvement we will be able to fully assess possible positive effects on value creation. This is left to future research.

\section{Acknowledgements}

We would like to acknowledge Martijn Blansjaar and Enrique Torres at MSF-H for their contribution to this research and the anonymous referees for their helpful comments. Furthermore, we would like to acknowledge all the individuals that cooperated with the questionnaires and interviews. All authors have contributed equally to this paper.

\section{References}

Adler, P.S. and Borys, B. (1996) 'Two types of bureaucracies: enabling and coercive', Administrative Science Quarterly, Vol. 41, pp.61-89.

Bacharach, S.B., Bamberger, P. and Sonnenstuhl, W. (1996) 'The organizational transformation process: the micropolitics of dissonance reduction and the alignment of logics of action', Administrative Science Quarterly, Vol. 41, pp.477-506.

Beamon, B.M. (2004) 'Humanitarian relief chains: issues and challenges', International Conference on Computers and Industrial Engineering, San Francisco, CA.

Beauregard, A. (1998) Civil-Military Cooperation in Joint Humanitarian Operations: A Case Analysis of Somalia, the Former Yugoslavia and Rwanda, Ploughshares Monitor, Waterloo, Canada. 
Bollen, M. and Beeres, R. (2008) 'Assessing the viability of civil-military cooperation in humanitarian opersions: allied harbour', in M. Bollen and S.J.H. Rietjens (Eds.): Managing Civil-Military Cooperation: A 24/7 Joint Effort for Stability, Ashgate, London.

Bollen, M. and Rietjens, S.J.H. (2008) Managing Civil-Military Cooperation: A 24/7 Joint Effort for Stability, Ashgate, London.

Carmel, E. and Tjia, P. (2005) Offshoring Information Technology Sourcing and Outsourcing to a Global Workforce, Cambridge University Press, Cambridge.

Cooper, K.G., Lyneis, J.M. and Bryant, B.J. (2002) 'Learning to learn, from past to future', International Journal of Project Management, Vol. 20, pp.213-219.

Corley, K.G. and Gioia, D.A. (2004) 'Identity ambiguity and change in the wake of a corporate spin-off', Administrative Science Quarterly, Vol. 49, pp.174-208.

Crowston, K. (1997) 'A coordination theory approach to organizational process design', Organization Science, Vol. 8, pp.157-175.

Denise, L. (1999) 'Collaboration vs. c-three (cooperation, coordination and communication)', Innovating, Vol. 7, No. 3, pp.1-6.

Edmondson, A.C., Bohmer, R.M. and Pisano, G.P. (2001) 'Disrupted routines: team learning and new technology implementation in hospitals', Administrative Science Quarterly, Vol. 46.

Fernie, J. and Staines, H. (2001) 'Towards an understanding of European grocery supply chains', Journal of Retailing and Consumer Services, Vol. 8, pp.29-36.

Fewell, S. and Clark, T. (2003) Organisational interoperability: evaluation and further development of the OIM Model, ICCRTS Conference (Washington, DC), available at, http://www.dodccrp.org.

Galbraith, J.R. (1973) Designing Complex Organizations, Addison-Wesley, Reading, Massachusetts.

Galunic, D.C. and Rodan, S. (1998) 'Resource recombinations in the firm: knowledge structures and the potential for Schumpeterian innovation', Strategic Management Journal, Vol. 19, pp.1193-1201.

Ghauri, P. and Grønhaug, K. (2005) Research Methods in Business Studies: A Practical Guide, Prentice Hall, Englewood Cliffs, NJ.

Gittell, J.H. and Weiss, L. (2004) 'Coordinating networks within and across organizations: a multi-level framework', Journal of Management Studies, Vol. 41.

Hinds, P. and Mcgrath, C. (2006) 'Structures that work: social structure, work structure and coordination ease in geographically distributed teams', CSCW 2006, ACM, Banff, Alberta.

Holmstöm, J., Främling, K., Kaipia, R. and Saranen, J. (2002) 'Collaborative planning forecasting and replenishement: new solutions needed for mass collaboration', Supply Chain Management: An International Journal, Vol. 7, No. 3, pp.136-145.

Huber, G.P. (1991) 'Organizational learning: the contributing processes and the literatures', Organization Science, Vol. 2, pp.88-115.

IFRC (1997) World Disasters Report, Kluwer, Norwell, MA.

Kaatrud, D.B., Samii, R. and van Wassenhove, L.N. (2003) 'UN joint logistics centre: a coordinated response to common humanitarian logistics concern', Forced Migration Review, Vol. 18.

Kaghan, W.N. and Lounsbury, M.D. (2006) 'Articulation work, collective mind, and the institutional residue of organizational artifacts', in A. Rafaelli and M.G. Pratt (Eds.): Artifacts and Organizations: Beyond Mere Symbolism, Lawrence Erlbaum, Mahwah, NJ.

Kamoche, K.N. (2001) 'Minimal structures: from jazz improvisation to product innovation', Organization Studies, Vol. 22.

Keizer, M. (2003) Logistics Information Project, MSF-H Internal Integration Report, Phase 1, November 2003. 
Kotlarsky, J. (2005) Management of Globally Distributed Component-Based Software Development Projects, Rotterdam School of Management, Erasmus University.

Kovács, G. and Spens, K.M. (2007) 'Humanitarian logistics in disaster relief operations', International Journal of Physical Distribution and Logistics Management, Vol. 37, pp.99-114.

Kumar, K., Van Fenema, P.C. and Von Glinow, M.A. (2005) 'Intense collaboration in globally distributed work teams: evolving patterns of dependencies and coordination', in D.L. Shapiro, M.A. Von Glinow and J.L.C. Cheng (Eds.): Managing Multinational Teams: Global Perspectives, Elsevier/JAI, Oxford.

Kurt Salmon Associates (1993) Efficient Consumer Response: Enhancing Consumer Value in the Supply Chain, Kurt Salmon Associates, Washington DC, USA.

Lee, A.S. (1989) 'A scientific methodology for MIS case studies', MIS Quarterly, Vol. 13, pp.33-50.

Mahoney, J.T. and Pandian, J.R. (1992) 'The resource-based view within the conversation of strategic management', Strategic Management Journal, Vol. 13.

Malhotra, N.K. and Birks, D.F. (2003) Marketing Research: An Applied Approach, 3rd ed., Pearson Education, Upper Saddle River, NJ.

Medair (2002) The ISO 9001 quality approach: useful for the humanitarian aid sector? Reliefweb.com, January 23rd 2002.

Miles, M.B. and Huberman, A.M. (1994) Qualitative Data Analysis: An Expanded Sourcebook, Sage, Thousand Oaks, CA.

Minear, L., Sott, C. and Weiss, T.G. (1996) The News Media, Civil War, and Humanitarian Action, Lynne Rienner, Boulder, CO.

Mintzberg, H. (1995) 'The structuring of organizations', in H. Mintzberg, J.B. Quinn and S. Ghoshal (Eds.): The Strategy Process, Prentice-Hall, London.

MSF (2005) MSF Financial Report.

Nevo, D. and Wand, Y. (2005) 'Organizational memory information systems: a transactive memory approach', Decision Support Systems, Vol. 39, pp.549-562.

Nonaka, I. and Takeuchi, H. (1995) The Knowledge-Creating Company, Oxford University Press.

Nonaka, I. (1994) ‘A dynamic theory of organizational knowledge creation', Organization Science, Vol. 5, No. 1, pp.14-37.

O'Sullivan, C. and Wild, N. (2007) NGO/Corporate Logistics Partnerships: The First Step, HumLog Conference, November 19-20, Cranfield, UK.

Oloruntobar, R. and Gray, R. (2006) 'Humanitarian aid: an agile supply chain', Supply Chain Management: An International Journal, Vol. 11, pp.115-120.

Orlikowski, W.J. (2002) 'Knowing in practice: enacting a collective capability in distributed organizing', Organization Science, Vol. 13, pp.249-273.

Oshri, I., Van Fenema, P.C. and Kotlarsky, J. (2008) 'Knowledge transfer in globally distributed teams: the role of transactive memory', Information Systems Journal (Forthcoming).

Owen, J., Burstein, F. and Mitchell, S. (2004) 'Knowledge reuse and transfer in a project management environment', Journal of Information Technology Cases and Applications, Vol. 6, pp.21-36.

Paasivaara, M. and Lassenius, C. (2003) 'Collaboration practices in global inter-organizational software development projects', Software Process Improvement and Practice, Vol. 8, pp.183-199.

Paho/Who (2001) Humanitarian supply management and logistics in the health sector, available at http://www.paho.org/English/PED/HumanitarianSupply-part1.pdf.

PMI Standards Committee (2000) A Guide to the Project Management Body of Knowledge, Project Management Institute, Newtown Square, PA. 
Porter, M.E. (1998) Competitive Advantage: Creating and Sustaining Superior Performance, Free Press, New York.

Powell, M. (2003) Information Management for Development Organisations, Oxfam Development Guidelines, 2nd ed., Oxfam Publishing, Oxford, UK.

Powell, W.W., Koput, K.W. and Smith-Doerr, L. (1996) 'Interorganizational collaboration and the locus of innovation: networks of learning in biotechnology', Administrative Science Quartely, Vol. 41, pp.116-145.

Rice, R.E. and Shook, D.E. (1990) 'Voice messaging, coordination, and communication', in J. Galegher R.E. Kraut and C. Egido (Eds.): Intellectual Teamwork: Social and Technological Foundations of Cooperative Work, Lawrence Erlbaum Associates, Hillsdale, New Jersey.

Rietjens, S.J.H., Voordijk, H. and De Boer, S.J. (2007) 'Coordinating humanitarian operations in peace support missions', Disaster Prevention and Management, Vol. 16, pp.56-69.

Shapiro, D.L., Von Glinow, M.A. and Cheng, J.L.C. (2005) Managing Multinational Teams: Global Perspectives, Elsevier/ JAI, Oxford.

Smith, K.G., Caroll, S.J. and Ashford, S.J. (1995) 'Intra- and interorganizational cooperation: toward a research agenda', Academy of Management Journal, Vol. 38, pp.7-23.

Stephenson Jr., M. (2004) 'Making humanitarian relief networks more effective: exploring the relationships among coordination, trust and sense making', National Conference of the Association for Research on Non-Profit Organizations and Voluntary Action (ARNOVA), Los Angeles, CA.

Stinchcombe, A.L. (1990) Information and Organizations, University of California Press, Berkeley, CA.

Tague, N.R. (2004) The Quality Toolbox, ASQ Quality Press, Milwaukee, WI.

Thomas, A. and Mizushima, M. (2005) 'Logistics training: necessity or luxury?', Forced Migration Review, Vol. 22, pp.60-61.

Thomas, A.S. and Kopczak, L.R. (2005) From logistics to supply chain management: the path forward in the humanitarian sector, Fritz Institute, Available at www.fritzinstitute.org.

Thomas, A.S. (2005) 'Humanitarian logistics: matching recognition with responsibility', Freight \& Logistics, pp.32-34.

Tomasini, R.M. and van Wassenhove, L.N. (2004) 'Moving the world: the TPG - WFP partnership, looking for a partner', Insead Case 02/2004-5187.

Transnational_Institute (2001) Reflections on Humanitarian Action, Pluto Press, London.

Tsoukas, H. (1996) 'The firm as a distributed knowledge system: a constructionist approach', Strategic Management Journal, Vol. 17, pp.77-91.

Van Fenema, P.C., Van Baalen, P.J. and Koppius, O.R. (2007) 'Implementing packaged enterprise software in multi-site firms: intensification of organizing and learning', European Journal of Information Systems, Vol. 16, pp.584-598.

van Wassenhove, L.N. and Samii, R.R. (2003) 'The United Nations joint logistics centre (UNJLC): the genesis of a humanitarian relief coordination platform', INSEAD Working Paper.

van Wassenhove, L.N. (2006) 'Humanitarian aid logistics: supply chain management in high gear', Journal of Operational Research Society, Vol. 57, pp.475-489.

von Hippel, E. (1994) 'Sticky information and the locus of problem solving: implications for innovation', Management Science, Vol. 40, pp.429-439.

Wegner, D.M. (1987) 'Transactive memory: a contemporary analysis of the group mind', in G. Mullen and G. Goethals (Eds.): Theories of Group Behavior, Springer Verlag, New York.

Weiss, T.G. and Collins, C. (2000) Humanitarian Challenges and Intervention, Westview Press, Boulder, CO.

Yin, R.K. (2003) Case Study Research: Design and Methods, Sage, Newbury Park, CA. 
Zhang, D., Zhou, L. and Nunamaker Jr, J.F. (2002) 'A knowledge management framework for the support of decision making in humanitarian assistance/disaster relief', Knowledge and Information Systems, Vol. 4, pp.370-385.

\section{Appendix 1 Interviews and questionnaires}

\begin{tabular}{|c|c|c|c|}
\hline Interview topics & $\begin{array}{c}\text { Task } \\
\text { environment }\end{array}$ & $\begin{array}{l}\text { Activity } \\
\text { cycles }\end{array}$ & $\begin{array}{l}\text { Information } \\
\text { cycles }\end{array}$ \\
\hline $\begin{array}{l}\text { Effectiveness of MSFs distributing } \\
\text { information's structure: justification, specific } \\
\text { problems and suggestions for improvements }\end{array}$ & $\mathrm{X}$ & $\mathrm{X}$ & $\mathrm{X}$ \\
\hline $\begin{array}{l}\text { Logistics knowledge transfer from previous } \\
\text { logs to new logs: within a certain project: } \\
\text { problem areas and suggestions for } \\
\text { improvement }\end{array}$ & $\mathrm{X}$ & $\mathrm{X}$ & $\mathrm{X}$ \\
\hline $\begin{array}{l}\text { Current state of information sharing between } \\
\text { projects and missions, indication of problem } \\
\text { areas and suggestions for improvement }\end{array}$ & $\mathrm{X}$ & $\mathrm{X}$ & $\mathrm{X}$ \\
\hline $\begin{array}{l}\text { Logistics website/FTP server/CD- } \\
\text { ROMS/logistics book kit/Habari-Tukul: } \\
\text { quality, accessibility, usage, structure and } \\
\text { amount of information, problems and } \\
\text { recommendations }\end{array}$ & & & $\mathrm{X}$ \\
\hline $\begin{array}{l}\text { Usage of the } \mathrm{H} \text {-drive (personal drive) for } \\
\text { storing and retrieving information }\end{array}$ & & & $\mathrm{X}$ \\
\hline $\begin{array}{l}\text { Usage of the G-drive (HQ's shared drive) for } \\
\text { storing and retrieving information }\end{array}$ & & & $\mathrm{X}$ \\
\hline $\begin{array}{l}\text { Assigned responsibilities on updating logistics } \\
\text { support information: clarity, problem areas, } \\
\text { suggestions for improvements }\end{array}$ & & & Encoding \\
\hline $\begin{array}{l}\text { Existing procedures on where to store logistics } \\
\text { information (website, CD-ROM, G-drive, } \\
\text { H-drive) and based on what criteria }\end{array}$ & & & Storing \\
\hline $\begin{array}{l}\text { Assigned responsibilities on storing logistics } \\
\text { support information: clarity, problem areas, } \\
\text { suggestions for improvements }\end{array}$ & & & Storing \\
\hline Usage of emails for storing information & & & Storing \\
\hline $\begin{array}{l}\text { Accessibility of this information. If not } \\
\text { accessible, the reasons }\end{array}$ & & & Storing \\
\hline Existing procedures on where to store reports & & & Storing \\
\hline Easiness in retrieving information & & & Retrieving \\
\hline Availability of information (missing info, etc.) & & & Retrieving \\
\hline $\begin{array}{l}\text { Information gathering: key contacts and } \\
\text { accessibility }\end{array}$ & & & Retrieving \\
\hline $\begin{array}{l}\text { Accessibility of reports: location and } \\
\text { relevance }\end{array}$ & & & Retrieving \\
\hline $\begin{array}{l}\text { Interviewees' tasks, daily activities, and } \\
\text { responsibilities }\end{array}$ & & $\mathrm{X}$ & \\
\hline
\end{tabular}




\section{Appendix 1 Interviews and questionnaires (continued)}

\begin{tabular}{|c|c|c|c|}
\hline Interview topics & $\begin{array}{c}\text { Task } \\
\text { environment }\end{array}$ & $\begin{array}{l}\text { Activity } \\
\text { cycles }\end{array}$ & $\begin{array}{l}\text { Information } \\
\text { cycles }\end{array}$ \\
\hline $\begin{array}{l}\text { Opinions on Keizer's recommendation on a } \\
\text { new structure to index information based on } \\
\text { subject and program (e.g., HIV, TB, etc.), its } \\
\text { appropriateness, constraints, replacement or } \\
\text { linkage with other sources }\end{array}$ & & $\mathrm{X}$ & \\
\hline $\begin{array}{l}\text { Communication with and within the logistics } \\
\text { department: regularity and means }\end{array}$ & & $\mathrm{X}$ & $\mathrm{X}$ \\
\hline $\begin{array}{l}\text { Effectiveness of MSFs distributing } \\
\text { information's structure: justification, specific } \\
\text { problems and suggestions for improvements }\end{array}$ & $\mathrm{X}$ & $\mathrm{X}$ & $\mathrm{X}$ \\
\hline $\begin{array}{l}\text { Logistics knowledge transfer: problem areas } \\
\text { and suggestions for improvement }\end{array}$ & $\mathrm{X}$ & $\mathrm{X}$ & $\mathrm{X}$ \\
\hline $\begin{array}{l}\text { Current state of information sharing between } \\
\text { projects and missions, indication of problem } \\
\text { areas and suggestions for improvement }\end{array}$ & $\mathrm{X}$ & $\mathrm{X}$ & $\mathrm{X}$ \\
\hline $\begin{array}{l}\text { Logistics website/FTP server/CD- } \\
\text { ROMS/Logistics book kit: quality, } \\
\text { accessibility, usage, structure and amount of } \\
\text { information, problems and recommendations }\end{array}$ & & & $\mathrm{X}$ \\
\hline $\begin{array}{l}\text { Usage of other information sources for } \\
\text { retrieving information }\end{array}$ & & & $\mathrm{X}$ \\
\hline Availability of information (missing info, etc.) & & & $\mathrm{X}$ \\
\hline $\begin{array}{l}\text { Information gathering: key contacts and } \\
\text { accessibility }\end{array}$ & & & $\mathrm{X}$ \\
\hline $\begin{array}{l}\text { Description of tasks, daily activities, and } \\
\text { responsibilities of the respondents interviewed }\end{array}$ & & $\mathrm{X}$ & \\
\hline
\end{tabular}




\section{Appendix 2 MSF-H Information platforms}

\begin{tabular}{|c|c|c|c|}
\hline Platform & $\begin{array}{c}\text { Responsible } \\
\text { unit }\end{array}$ & Purpose and short description & Direction \\
\hline \multicolumn{4}{|c|}{1 Information storage and distribution } \\
\hline $\begin{array}{l}\text { Logistics } \\
\text { website }\end{array}$ & FSU & $\begin{array}{l}\text { Information exchange (password protected) } \\
\text { between capital level and HQ level, where HQ } \\
\text { holds ownership of the information. } \\
\text { Information is categorised according to: } \\
\text { department, latest news, training and HRM, } \\
\text { logistic field information, procurement unit, } \\
\text { building and shelter, cold chain, } \\
\text { communication, energy, ICT, supply and } \\
\text { logistics management, vehicles and transport } \\
\text { and water and sanitation. }\end{array}$ & Downstream \\
\hline FTP server & FSU & $\begin{array}{l}\text { Transfer of large documents on any topic from } \\
\text { HQ to capital level and field level. Documents } \\
\text { should only be sent on an individual basis and } \\
\text { upon request. The server also contains a library } \\
\text { of general and specific documents per country. }\end{array}$ & $\begin{array}{c}\text { Downstream } \\
\text { Upstream }\end{array}$ \\
\hline $\begin{array}{l}\text { FSU } \\
\text { CD-ROM }\end{array}$ & FSU & $\begin{array}{l}\text { Contains updates for virus scans, windows } \\
\text { service packs, etc., plus the contents of the } \\
\text { logistics website to guarantee availability at } \\
\text { field level; is renewed every four to six weeks. }\end{array}$ & Downstream \\
\hline $\begin{array}{l}\text { Logistics } \\
\text { reference } \\
\text { material }\end{array}$ & FSU & $\begin{array}{l}\text { CD-ROMs containing training material, supply } \\
\text { training package, self-learning logistics course, } \\
\text { reference books, first missioners' logistics } \\
\text { preparation course; hard copies of training } \\
\text { material and yellow guidelines. }\end{array}$ & Downstream \\
\hline $\begin{array}{l}\text { Information } \\
\text { technology } \\
\text { service }\end{array}$ & FSU & $\begin{array}{l}\text { Database that includes frequently asked } \\
\text { questions (FAQs) from the field. Front officer } \\
\text { should update regularly. At the time of research } \\
\text { it was not working at full capacity and was not } \\
\text { accessible at the field. }\end{array}$ & $\begin{array}{c}\text { Downstream } \\
\text { Upstream }\end{array}$ \\
\hline $\begin{array}{l}\text { Field } \\
\text { library } \\
\text { catalogue }\end{array}$ & IDC & $\begin{array}{l}\text { A yearly list of books, documents, CD-ROMs, } \\
\text { etc. compiled by the IDC in close operation } \\
\text { with the different specialists in the office: basic } \\
\text { book kits (obligatory in every project), } \\
\text { emergency book kits (highly recommended), } \\
\text { subject kits (specialised books). }\end{array}$ & Downstream \\
\hline Habari & IDC & $\begin{array}{l}\text { Intranet of MSF-H; can be accessed by HQ and } \\
\text { field level (latter only at very slow speed). } \\
\text { Contains country and project overview; Field } \\
\text { and office related news; expat schedule for } \\
\text { briefings and debriefings; vacancies and more. }\end{array}$ & Downstream \\
\hline
\end{tabular}




\section{Appendix $2 \quad$ MSF-H Information platforms (continued)}

\begin{tabular}{|c|c|c|c|}
\hline Platform & $\begin{array}{l}\text { Responsible } \\
\text { unit }\end{array}$ & Purpose and short description & Direction \\
\hline \multicolumn{4}{|c|}{$1 \quad$ Information storage and distribution } \\
\hline $\begin{array}{l}\text { Project } \\
\text { information }\end{array}$ & IDC & $\begin{array}{l}\text { Project information that is sent to IDC contains } \\
\text { the following documents: general information } \\
\text { (welcome/expat guidelines, maps and pictures), } \\
\text { situational reports, management reports, } \\
\text { country policies and security guidelines, other } \\
\text { field experience reports (explos, assessments, } \\
\text { trip reports), proposals. This information is } \\
\text { filed per country per subject. }\end{array}$ & Downstream \\
\hline $\begin{array}{l}\text { Treasury } \\
\text { CD-ROM }\end{array}$ & IDC & $\begin{array}{l}\text { Policy papers, manuals, discussion papers, } \\
\text { guidelines (including logistics yellow } \\
\text { guidelines) of MSF in general and MSF-H in } \\
\text { particular. }\end{array}$ & Downstream \\
\hline TUKUL & IDC & $\begin{array}{l}\text { MSFs international intranet, divided into } \\
\text { TUKUL international space (the international } \\
\text { document management system of MSF, } \\
\text { available to MSF-international offices only; } \\
\text { contains operational news from the various } \\
\text { operational centers) and TUKUL MSF-H } \\
\text { documents (the international document } \\
\text { management system of MSF; can be accessed } \\
\text { by HQ and field level, latter only at very slow } \\
\text { speed; contains project information and the } \\
\text { latest expat list). }\end{array}$ & $\begin{array}{l}\text { Downstream } \\
\text { Upstream }\end{array}$ \\
\hline \multicolumn{4}{|c|}{2 Knowledge transfer } \\
\hline Briefings & FSU & $\begin{array}{l}\text { Briefing before departure to Logs and } \log \operatorname{Cos} \\
\text { Logistics support information is given. }\end{array}$ & Downstream \\
\hline $\begin{array}{l}\text { Training } \\
\text { programs }\end{array}$ & FSU & $\begin{array}{l}\text { Pre-departure course (PPD) for first missioners, } \\
\text { general information on MSF (one week); } \\
\text { technical logistics course (TLC): two weeks; } \\
\text { logistics management course (LMC); vehicle } \\
\text { course; water and sanitation course; ICT } \\
\text { training and LogCo training skills (three days), } \\
\text { usually before annual LogCo days. }\end{array}$ & Downstream \\
\hline $\begin{array}{l}\text { Annual } \\
\text { LogCo } \\
\text { meeting }\end{array}$ & FSU & LogCo days (annual one week-meeting). & $\begin{array}{l}\text { Downstream } \\
\text { Upstream } \\
\text { Horizontal }\end{array}$ \\
\hline
\end{tabular}

